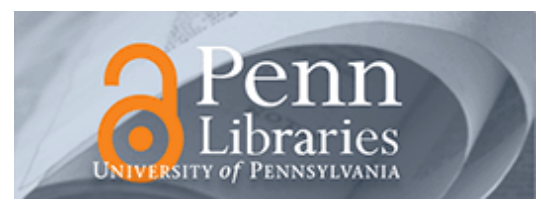

University of Pennsylvania ScholarlyCommons

\title{
Transparency through Insurance: Mandates Dominate Discretion
}

Tom Baker

University of Pennsylvania

Follow this and additional works at: https://repository.upenn.edu/hcmg_papers

Part of the Health Law and Policy Commons, Insurance Commons, and the Insurance Law Commons

\section{Recommended Citation (OVERRIDE)}

Baker, T. (2012). Transparency through Insurance: Mandates Dominate Discretion. In Doherty, J.W., Reville, R.T., \& Zakaras, L. (Eds.), Confidentiality, Transparency, and the U.S. Civil Justice System, (pp. 184-200). New York: Oxford University Press.

This paper is posted at ScholarlyCommons. https://repository.upenn.edu/hcmg_papers/3

For more information, please contact repository@pobox.upenn.edu. 


\title{
Transparency through Insurance: Mandates Dominate Discretion
}

\author{
Abstract \\ This chapter describes how liability insurance has contributed to the transparency of the civil justice \\ system. The chapter makes three main points. First, much of what we know about the empirics of the civil \\ justice system comes from access to liability insurance data and personnel. Second, as long as access to \\ liability insurance data and personnel depends on the discretion of liability insurance organizations, this \\ knowledge will be incomplete and, most likely, biased in favor of the public policy agenda of the \\ organizations providing discretionary access to the data. Third, although mandatory disclosure of liability \\ insurance data would improve transparency, a reasonably complete understanding of the empirics of the \\ civil justice system also requires mandatory disclosure of the payments and defense expenditures that \\ are not covered by alternative risk transfer arrangements. \\ Disciplines \\ Health Law and Policy | Insurance | Insurance Law
}

This book chapter is available at ScholarlyCommons: https://repository.upenn.edu/hcmg_papers/3 


\section{CONFIDENTIALITY, TRANSPARENCY, AND THE U.S. CIVIL JUSTICE SYSTEM}

Edited by Joseph W. Doherty

Robert T. Reville

Laura Zakaras 


\section{OXFORD}

UNIVERSITY PRES

Oxford University Press, Inc., publishes works that further Oxford University's objective of excellence in research, scholarship, and education.

Oxford New York

Auckland Cape Town Dar es Salaam Hong Kong Karachi Kuala Lumpur Madrid Melbourne Mexico City Nairobi New Delhi Shanghai Taipei Toronto

With offices in

Argentina Austria Brazil Chile Czech Republic France Greece Guatemala Hungary Italy Japan Poland Portugal Singapore South Korea Switzerland Thailand Turkey Ukraine Vietnam

Copyright $\odot 2012$ by Oxford University Press, Inc.

Published by Oxford University Press, Inc.

198 Madison Avenue, New York, New York 10016

Oxford is a registered trademark of Oxford University Press

Oxford University Press is a registered trademark of Oxford University Press, Inc.

All rights reserved. No part of this publicarion may be reproduced, stored in a retrieval system, or transmitted, in any form or by any means, electronic, mechanical, photocopying, recording, or orherwise, without the prior permission of Oxford University Press, Inc.

Special sale edition ISBN 978-0-19-992197-3 (hardback : alk, paper)

\section{Library of Congress Cataloging-in-Publication Data}

Confidentiality, transparency, and the U.S. civil justice system / edited by Joseph W. Doherty, Roberr T. Reville, Laura Zakaras. p. $\mathrm{cm}$.

Includes bibliographical references and index.

ISBN 978-0-19-991433-3 (hardback : alk. paper)

1. Justice, Administration of-United States.

2. Disclosure of information-Law and legislation-United States

3. Confidential communications-United States.

I. Doherty, Joseph W. II. Reville, Robert T. III. Zakaras, Laura.

KF8700.C658 2012

$347.73-\mathrm{dc} 23$

\section{1}

Printed in the United States of America on acid-free paper

Note to Readers:

This publication is designed to provide accurate and authoritative information in regard to the subject matter covered. It is based upon sources believed to be accurate and reliable and is intended to be current as of the time it was written. It is sold with the understanding that the publisher is not engaged in rendering legal, accounting, or other professional services. If legal advice or other expert assistance is required, the services of a competent professional person should be sought. Also, to confirm that the information has not been affected or changed by recent developments, traditional legal research techniques should be used, including checking primary sources where appropriate.

(Based on the Declaration of Principles jointly adopted by a Committee of the American Bar Association and a Committee of Publisbers and Associations.)

You may order this or any other Oxford University Press publication by visiting the 0 xford University Press website at www.oup.com 


\section{TRANSPARENCY THROUGH INSURANCE: MANDATES DOMINATE DISCRETION}

\section{Tom Baker ${ }^{1}$}

This chapter describes how liability insurance has contributed to the transparency of the civil justice system. The chapter makes three main points. First, much of what we know about the empirics of the civil justice system comes from access to liability insurance data and personnel. Second, as long as access to liability insurance data and personnel depends on the discretion of liability insurance organizations, this knowledge will be incomplete and, most likely, biased in favor of the public policy agenda of the organizations providing discretionary access to the data. Third, although mandatory disclosure of liability insurance data would improve transparency, a reasonably complete understanding of the empirics of the civil justice system also requires mandatory disclosure of the payments and defense expenditures that are not covered by alternative risk transfer arrangements.

The first part of this chapter describes existing approaches to transparency through liability insurance in the United States. The second part analyzes the role of liability insurance in promoting transparency in several discrete civil justice arenas-auto, medical, and products liability-and, for comparison purposes, workers' compensation. The concluding section addresses objectives to expanding mandatory claims reporting and links the discussion in this chapter to the literature on the relationship between liability and insurance more generally.

1. University of Pennsylvania Law School. Thank you to Ina Ebert, Christian Lahnstein, James Macdonald, Robert Reville, and Charles Silver for comments 


\section{Existing Approaches to Transparency Through Liability Insurance}

The terms "transparency" and "civil justice system" require definition. For present purposes, "transparency" refers to the degree to which the system is open to public view for (a) direct observation and (b) systematic analysis by researchers so that general understandings about the operation of the system can be drawn. For present purposes, the "civil justice system" refers to the institutions centrally involved in providing redress for individuals who have been harmed in some way that is recognized as compensable through tort or related liability law. Under this expansive definition, the civil justice system includes courts, law firms, governmental legal offices or agencies (such as state attorney general offices), parts of the organized bar, other organizations that assist claimants or defendants, and liability insurance institutions. Massively repeat players such as health insurance and workers' compensation companies (which have subrogation rights in thousands of claims) and defendants with very large claims portfolios (such as utilities and governmental entities) might also appropriately be regarded as part of the civil justice system, not just users of the system, particularly when they develop specialized organizational structures for the resolution of claims for civil redress.

These definitions help make clear that liability insurance is both part of the civil justice system and also a window through which to observe other parts of the system. Liability insurance institutions themselves vary in their transparency and can thus provide either a more or less transparent window on many aspects of the civil justice system: the aggregate sums transferred through different categories of claims over time, the amounts paid to different categories of victims, the timing of the resolution of different categories of claims, the fees paid to plaintiffs and defense counsel, and the amount and distribution of settlement payments to subrogating first-party insurers, to name just a few topics that could be illuminated through access to insurance industry data.

Liability insurance contributes to the transparency of the civil justice system in the United States through the following channels: (1) discretionary access to insurance company data and personnel; (2) public access to data collected and analyzed by insurance industry information service providers; (3) public access to the financial reports filed with regulatory authorities; and (4) public access to the mandatory claim-level reporting required in the medical liability arena. The following sections describe each of these. 


\section{Discretionary Access to Liability Insurance Company Information}

The liability insurance industry has a long history of providing information to civil justice researchers on a voluntary basis. $H$. Laurence Ross's renowned study of automobile liability law-in-action was possible only because two major auto insurance companies permitted him to observe and interview their automobile insurance adjusters (Ross 1970). Most of the medical liability closed claims studies were possible only because medical liability insurers provided access to researchers (summarized in Baker 2005a; see also Studdert, et al. 2006). Liability insurers have provided civil justice researchers with computerized claims data that have made it possible to assess the impact of legal rules on litigation and settlement (e.g., Yoon 2001; Yoon and Baker 2006). In addition, liability insurance industry personnel have participated in qualitative civil justice research and in survey research (e.g., Baker 2001; Carroll, et al. 2005; Pace, et al. 2007; Baker and Griffith 2011).

At the same time, however, the liability insurance industry has a long history of refusing to provide information to civil justice researchers. For a researcher, the process of obtaining access to insurance company information is time consuming and uncertain at best. One risk-averse person in a long chain of command is enough to stop any research project. And who, really, can blame that risk-averse person? Granting researchers access to insurance company data is a public service that is unlikely to provide any private benefit to the company that provides the access.

Liability insurers on the whole do, however, benefit from greater understanding of the operation of the civil justice system and, thus, granting access to researchers can be understood in some cases as one insurer's contribution to the success of the industry as a whole. In other cases, the decisionmakers in the company may be curious or public-spirited, and the public access may be understood as a form of charitable contribution. In either event, however, case-by-case decisions by individual insurance companies to provide voluntary access to civil justice researchers cannot serve as a reliable foundation for civil justice transparency, as important as that access in fact has been to some researchers (e.g., Rolph, et al. 2007).

Discretionary access to liability insurance data cannot serve as a reliable foundation for two structural reasons that have nothing to do with the limits of the data. First, liability insurers derive a competitive advantage from having better data than the competition, and they cannot reasonably be expected to give away that advantage. Better data allow for pricing that is more finely attuned to the risk, providing a competitive advantage in the adverse selection 
"arms race" at the underwriting stage of the insurance relationship (Baker 2003), and better data should lead to a better understanding of the claims environment, providing a competitive advantage in selecting and pricing claims for settlement.

Second, the liability insurance organizations have interests at stake in public policy debates that can be affected by research on the civil justice system. Those interests provide an incentive to be selective in granting discretionary access to data. Research that rests on voluntarily provided data is very likely to be biased in favor of the perceived interests of the organization providing the data-for the very human and very understandable reason that people are more likely to give things to people whom they see as allies. A researcher whose prior research is seen as contrary to an insurer's public policy agenda is much less likely to be given access to data than a researcher whose prior research is seen as helpful to that agenda.

\section{Public Access to Insurance Industry Information Service Providers}

Liability insurers need to understand the civil justice system in order to price insurance and manage claims. Thus it is hardly surprising that the industry collects and analyzes civil justice data. Some of these data are shared among insurance companies, typically through insurance industry information service providers. This information is generally not available to civil justice researchers, however, and thus does not contribute to civil justice transparency.

Traditionally, the most important liability insurance industry service provider in the United States has been the Insurance Services Office (ISO), Inc., which collects and analyzes a wide variety of liability insurance data. ${ }^{2}$ ISO also serves for some purposes as the interface between insurance companies and the regulatory authorities and, thus, fills a quasi-regulatory role. ISO collects individual claim-level data from member companies, but it does not make those data available to researchers. ISO uses the data to estimate prospective loss costs that its members can use for pricing purposes and to provide required information to state insurance regulatory authorities.

The ISO database is not designed to be a policy or individual claim-level database but rather a company-level database. Thus, it appears that the ISO data would be useful for estimating trends in aggregate claim costs within and among member companies on a state-by-state basis. This could be very useful

2. Information about ISO is based on a phone conversation with ISO government affairs official Mary Size, October 3, 2007. 
for studying the impact of state-level changes in liability law, among other civil justice topics of interest. ISO regards the individual and company-level data as confidential, however, and does not make it available to researchers. ISO does prepare reports using the aggregate information and would consider on a case-by-case basis whether to permit researchers to use the aggregate data.

The Insurance Research Council (IRC) is a significant exception to the general rule of refusing to grant civil justice researchers access to data. The IRC has played a major role in increasing the transparency of automobile accident claiming, the largest part of the liability insurance market. Every five years since 1987, the IRC has collected and then published two signifcant claims-level data sets. The first data set in each year is closed claim data provided by auto insurance companies that collectively account for 65-70 percent of auto insurance by premium volume. Each participating company establishes a two-week window in the spring and fills out a form for every auto claim closed with payment during that window. The result is a closed claim file with about 80,000 claims for each year.

The second data set is a survey of a nationally representative panel of consumers from approximately the same time as the claims data are collected. The IRC survey asks a variety of questions about consumption patterns, including whether anyone in the household was injured in an auto accident in the previous three years. If so, the participants are asked questions about injuries, claims, and compensation. These data provide information on other sources available for compensation for auto injuries, on injuries that do not produce an auto insurance claim, and on injuries from claims that are dropped or denied. Both data sets have been useful to civil justice researchers (e.g., Carroll and Abrahamse 2001).

\section{Access to Mandatory Financial Reporting}

Public insurance companies admitted to do business in the United States must provide financial reports to the insurance regulatory authorities. The regulatory authorities aggregate this financial information and provide public access under the auspices of the National Association of Insurance Commissioners (NAIC). The underlying, company-by-company data are available for purchase, and researchers have made good use of these data to study trends in the costs of civil justice and the effects of state-level legal changes (Born, et al. 1998). In addition, a variety of information service providers purchase this financial information and repackage it in forms that can be useful to civil justice researchers. For example, Best's Aggregates and Averages, has long 
provided aggregate financial information about a substantial part of the civil justice system that is very useful for monitoring trends in liability costs over time (Baker 2005b).

All of these financial data have very serious limitations, however, relating to the fact that the underlying financial reports are designed to allow insurance regulators to monitor the solvency of liability insurance companies and in some cases to assess insurance company rating plans, not to provide civil justice transparency. This design objective affects the data in many ways, only three of which will be described here.

First, the financial reports contain more detailed information about "incurred" losses than they do about either "developed" losses or paid claims. Incurred losses are accounting entries that reflect the insurers' obligation to pay claims in the future. The decision to focus on future predicted payments rather than payments actually made in the past makes a great deal of sense from a solvency perspective, because an insurer's obligations to pay future claims has a greater impact on the solvency of the company than money it has already paid. Unfortunately, predictions about future claims are subject to a well-documented but complicated and poorly publicized insurance industry business cycle-the "underwriting cycle." This underwriting cycle leads to periodic insurance crises that involve rapid increases in predicted losses (Baker 2005b). Because of this cycle and because of money illusion (i.e., the common tendency to forget that a unit of money spent in the past had greater value than the same unit of money has today because of inflation), it is easy to selectively present the incurred loss information in a way that makes it appear as if the civil justice system is growing explosively when, in reality, claim payments are increasing at about the same rate as inflation (compare TillinghastTowers Perrin 2002 with Tillinghast-Towers Perrin 2007).

Second, the aggregate premium information does not reveal the price for insurance coverage, particularly on an annual basis. ${ }^{3}$ The underwriting cycle affects many aspects of the insurance contract, not just price. Insurance contract terms become more restrictive during a hard market and less restrictive over the course of a softening market. Because buyers are likely to adjust the amount of coverage that they buy in response to the cycle, changes in aggregate premiums on a year-to-year basis likely understate price changes in any given year. For example, a large increase in the aggregate premiums at the start

3. Surveys of insurance prices, such as the annual reports of the Medical Liability Monitor, provide useful information, but recent research suggests that the "list prices" reported in these surveys differ significantly from the prices that actually are paid (Rodwin, et al. 2008). 
of the hard market likely understates the increase in insurance prices, because buyers raise their deductibles and decrease their policy limits in response to the higher prices. Moreover, insurance companies may be simultaneously introducing more restrictive contract terms, thereby reducing the extent of the insurance protection provided. Similarly, stable aggregate premiums during the latter part of a soft market may well hide declining prices, even ignoring inflation, as buyers reduce deductibles and increase limits in response to a lower price.

Third, the reports do not provide any information about liabilities that are not covered by liability insurance. Captive insurance companies, risk retention groups, and other organizations that provide alternatives to traditional insurance are not required to file these reports. Nor are organizations that self-insure through means other than captive insurance companies. As a result, Best's Aggregates and Averages and other compilations of the NAIC data do not provide any information about the claims or losses or prices of these alternative risk transfer or retention options. This omission is very significant for liabilities that are commonly covered by alternative risk transfer arrangements, such as medical and product liabilities. Moreover, because there is reason to believe that the extent of insured losses varies along with the underwriting cycle, efforts to measure the civil justice system using the NAIC data are likely to present a misleading picture of the rate and direction of change (e.g., Tillinghast-Towers Perrin 2007).

\section{Public Access to Closed Claim Reports}

The medical malpractice arena provides an exception to the general rule that liability insurance companies do not provide public access to their closed claim reports. Medical malpractice insurance companies in the United States are required by law to file two kinds of claim reports:

- National Practitioner Data Bank (NPDB). Insurance companies and other malpractice payers are required to file reports with the National Practitioner Data Bank (NPDB) that provide information about any medical malpractice payment made for the benefit of a physician, dentist, or other health care practitioner (HHS 2001). While reports filed with the NPDB are not public, the NPDB does release information in forms that are useful for research purposes. It is possible to track claim payments by state, specialty, and date. Beginning in 2004, it became possible to track 
payments by type of allegation and injury. ${ }^{4}$ Unfortunately, the NPDB only contains reports for payments made on behalf of individual practitioners. It does not contain reports of payments made on behalf of entities such as hospitals or urgent care centers. There are anecdotal reports that malpractice claim settlements are sometimes structured so that one or more defendant entities pay the entire settlement and thus no report needs to be filed regarding a practitioner defendant. This possibility compromises the usefulness of the NPDB. Nevertheless, the limited public access to the NPDB has enhanced the transparency of the medical malpractice aspect of the civil justice system (e.g., Baicker and Chandra 2005; Chandra, et al. 2005; Dhankar, et al. 2007).

- State Closed Claim Data. Some states in the United States also require medical malpractice insurance companies to file individual closed claim reports to the insurance regulatory authorities, typically for medical liability claims (Cohen and Hughes 2007). Two large states-Florida and Texas-have long permitted public access to those reports, and a third state, Missouri, makes its database available to academic researchers. Building on that experience, in 2008, the National Association of Insurance Commissioners adopted a model law that provides a framework for more states to collect this information on a more uniform basis. ${ }^{5}$ Though the model law applies only to medical liability and leaves open the question of public access, it does mandate reporting from nontraditional insuring entities, such as captive insurance companies and risk retention groups.

In most cases, these regimes were established during highly pressured legislative drafting sessions at the height of liability insurance crises, without input from civil justice researchers. As a result, they have a number of shortcomings, including the following:

- The information the states collect is not uniform,

- The closed claim report forms often do not require insurers to provide information about the severity of the injuries or other important claimspecific information,

- Little or no information is collected about claims that are closed with no payment or a small payment,

4. Hetp://www.npdb-hipdb.hrsa.gov/resources/publicData.jpp.

5. Medical Professional Liability Closed Claim Reporting Model Law, NAIC Model Laws, Regulations and Guidelines 77-1, \$\$1-8 (2008) available through Lexis Nexis. 
- In some cases there are doubts about the accuracy of the information that the insurance companies provide,

- In most cases, the reports must be filed only for medical liability claims, and

- Most states do not permit civil justice researchers to analyze the data. There are, however, a few notable exceptions, including Texas, Florida, Missouri, Virginia, Connecticut, and Michigan, though even these states are not immune from the concerns above.

Yet, despite this gap between the actual and the ideal, the mandatory closed claim reports have made a very substantial contribution to knowledge of the medical liability part of the civil justice system. Each of the now increasing number of articles published by the research teams analyzing the Florida and Texas data has made a significant contribution (e.g., Black, et al. 2005; Black, et al. 2008; Black, et al. 2009; Hersch, et al. 2010; Hyman, et al. 2007; Hyman, et al. 2009; Paik, et al. 2010; Silver, et al. 2008; Vidmar, et al. 2005; Vidmar, et al. 2006; Zeiler, et al. 2007). In many cases, the articles demonstrate that a common belief about the civil justice system is mistaken. While deeply entrenched opposition to this knowledge has largely prevented this research from changing public understanding (Baker 2005a; Haltom and McCann 2004), this information has improved the public policy debate by educating journalists and legislators.

Although accessible insurance company closed claim reports are not a panacea, they offer an approach to improving the transparency of the civil justice system, particularly if the reporting requirements were also imposed on nontraditional insuring entities currently exempt from reporting requirements. In that regard, the NPDB represents only a partially successful model. The NPDB imposes reporting obligations on anyone who pays on behalf of a medical practitioner, not just insurance companies, but it does not impose any reporting obligations for payments on behalf of hospitals and other entities.

\section{Liability Insurance and Transparency in Selected Civil Justice Areas}

The preceding section described different ways that civil justice researchers can obtain access to liability insurance claims information. This section describes how they can find liability insurance information about specific kinds of claims: automobile accidents, medical injuries, products injuries, 
consumer fraud, securities fraud, and, for comparison purposes, occupational injuries. There are very substantial differences across these fields in the kinds of insurance data that are publicly available and, thus, in the degree to which liability insurance promotes transparency.

\section{Automobile Accidents}

Automobile liability claims are the single largest category of tort claims in the United States, reflecting the ubiquity of both the automobile and automobile liability insurance. With very limited exceptions, automobile liability insurance is mandatory in the United States. As a result, liability insurance is nearly coextensive with automobile liability, and, therefore, liability insurance institutions have the potential to provide nearly comprehensive data about this part of the civil justice system.

At the aggregate level in the United States, automobile insurers that are subject to the NAIC financial reporting requirements cover the vast majority of automobile liabilities. Thus, the NAIC financial data provide a good guide to aggregate developments in auto liability losses over time. While these data are subject to the limitations discussed earlier, the underwriting cycle in automobile insurance is less dramatic than in other areas such as medical and products liability (Baker 2004).

At the individual claim-level, companies that provide information services to insurers have a very rich and detailed understanding of the automobile claim settlement environment. Although the IRC data are expensive, they are available to civil justice researchers, and RAND has put them to good use (e.g., Carroll and Abrahamse 2001).

Thanks to the fieldwork of $H$. Laurence Ross, civil justice researchers once had a detailed understanding of automobile insurance claims handling (Ross 1970). That fieldwork was carried out in the 1960s, however, well before the development of call centers, computerized claims settlement models, and the other features of the contemporary auto-claiming environment. As a result, it seems quite likely that Ross's description is out of date in important respects.

\section{Medical Injuries}

In recent years, medical injuries have been subject to intensive civil justice research in the United States (collected in Baker 2005a). For example, the extensive closed claim research has now conclusively rejected the charge that 
medical liability claims are paid in the United States without regard to the merits (Studdert, et al. 2006; Peters Jr. 2007). Yet key facts about the medical liability landscape in the United States remain in hot dispute, most significantly, facts relating to the severity of medical liability claims and to the aggregate financial dimensions of medical liability.

For reasons that are not well documented, a substantial fraction of the medical liability risk is spread outside of traditional liability insurance institutions or is retained by large health care organizations (Tillinghast-Towers Perrin 2007). As a result, the financial reports filed by liability insurance companies do not provide a reliable window on the financial dimensions of medical liability risk. The percentage of the medical liability risk that lies outside the reach of traditional liability insurance is unknown, and the large price swings that result from the insurance underwriting cycle in the medical liability field provide reason to believe that there is substantial movement into and out of the traditional liability insurance market over time (Baker 2005b).

There are no organizations that collect and release medical liability information comparable to that collected and released by IRC and ISO for automobile accident claims. As described earlier, some states require liability insurers to file closed claim reports with the state insurance departments and the National Practitioner Data Bank grants limited public access. But those closed claim reports are subject to the limitations described earlier in this chapter.

Some medical liability insurance companies have provided civil justice researchers with access to their closed claim files and the resulting research has made a substantial contribution to the field (e.g., Studdert, et al. 2006). But due to the highly politicized nature of medical liability, insurers have tended to provide access only to researchers associated with medical institutions. This is a concrete example of the bias that can result from relying on discretionary access to insurance data. ${ }^{6}$ Most civil justice researchers have been unable to gain access to closed claim files, except through the very limited information that is provided to state insurance departments in Florida, Texas, and Missouri. The NAIC Model Law leaves open the issue of researcher access to the closed claim reports, so states that adopt that módel law face an important decision. Providing full access to researchers will undoubtedly enhance our understanding of the medical malpractice aspect of the civil justice

6. Of course, access to medical institutions is much better than no access at all. The professional association of anesthesiologists, for example, has used liability insurance claim data as part of a safety program that has achieved dramatic reductions in patient injuries (Cooper 2006). 
system. Unfortunately, the two states-Oklahoma ${ }^{7}$ and Tennessee ${ }^{8}$ - that have adopted the model law have both opted to deny public access to all contents of the reports. To date, there has been no effort to study the handling of medical liability insurance claims using qualitative methods comparable to Ross's study of auto liability insurance claims handling. This would be a worthy area for future research.

\section{Products Injuries}

Liability insurance provides even less systematic information about the product injury portion of the civil justice system in the United States. As with medical injuries, the insurance underwriting cycle plays a significant role in the movement of product liability risk into and out of traditional liability insurance arrangements. In addition, as with medical injuries, a substantial but uncertain portion of the risk is shifted to nontraditional liability insurance arrangements that are exempt from the NAIC financial reporting regime. For example, there is reason to believe that at least a plurality, if not a majority, of pharmaceutical liability risks do not purchase traditional liability insurance in the United States (Dowding 2006).

There are additional limits on what can be learned from liability insurance information in the products context that go well beyond the limits in the medical liability context in the United States. First, with the possible exception of Texas, there are no mandatory closed claim reporting regimes for products liability similar to those in the medical liability arena. Second, asbestos claims cast a large shadow over products liability that makes it difficult to interpret aggregate products liability claiming and payment data. Third, there is reason to believe that manufacturers and other entities with significant products liability risk typically purchase liability insurance programs with a very substantial "self-insured retention" (essentially, a very large deductible), and these entities very often have in-house facilities for handling tort claims, or use third-party-claims management services to handle claims within the retention.

As a result, a substantial but uncertain portion of products liability claims against defendants that do purchase traditional liability insurance would not be reflected in liability insurance company claims or loss data. Product

7. Medical Professional Liability Closed Claims Reports Act. 2009. Oklahoma Statutes, Annotated. Vol. 36, sec. 6816.

8. Tennessee Medical Malpractice Reporting Act. 2008. Tennessee Code, Annotated. Title 56, Chap. 54, sec. 107. 
liability claims that ripen into mass torts present additional complications relating to the involvement of large numbers of liability insurance policies and liability insurance companies, even in cases in which the mass tort actions are directed at a single manufacturer. Moreover, in some cases there are very significant disputes over the extent to which the claims are covered by all or part of the liability insurance program, with the result that claims are handled by the defendant manufacturer, and the liability insurers pay a lump sum amount in settlement of their obligations and do not maintain claim-specific files (Abraham 2001).

\section{Consumer Fraud}

States have enacted a variety of statutory regimes that provide liability for consumer fraud. Because consumer fraud is not covered by liability insurancewith the exception of securities fraud, which is covered by D\&O insurance (Baker and Griffith 2011) - liability insurance obviously does not provide a window on this aspect of the civil justice system. Other important kinds of civil justice claims that fall outside the insurance umbrella are contract claims and claims involving real estate transactions.

\section{Occupational Injuries and Workers' Compensation}

Occupational injuries are subject to workers' compensation laws in the United States, and the vast majority of employees are covered by workers' compensation insurance. Although there are substantial differences in the details of workers' compensation arrangements across states, most of these systems include strong reporting requirements that make workers' compensation claim payments more transparent than claim payments in most parts of the civil justice system. However, the administrative nature of the formal workers' compensation claims process is less transparent than the formal, court-centered process of the civil justice system. Still, because much of the real work of the civil justice system takes place in insurance company claim offices and in settlements negotiated among the parties, the level of transparency of the two systems may not be so different.

Workers' compensation insurance claims reporting is governed by statistical plans promulgated by the insurance departments of each state. Most of these plans are standardized and administered by the National Council on Compensation Insurance (NCCI). Pursuant to these plans, workers' compensation insurance companies file detailed electronic reports at the individual 
claim level that identify such information as the date of the claim, the occupational class of the employer and employee, and the incurred loss (incurred loss includes both past and projected future payments). ${ }^{9}$ In the past the individual claim-level data has not included the nature of the injury, but that information may be collected in the future. These data are available to researchers, and NCCI and other workers' compensation experts are notably available to talk to researchers through the NCCI Annual Issues Symposium.

Self-insured workers' compensation plans are not required to file reports with state insurance departments. They do report some data directly to the state workers' compensation agency, but these data are not standardized and aggregated by the NCCI. As a result, describing the aggregate operation of the workers' compensation system requires some extrapolation and estimation. With that said, the available data make it possible to describe the workers' compensation claiming universe more accurately and comprehensively than any part of the civil justice system, with the possible exception of medical malpractice in Florida, Missouri, and Texas.

\section{Increasing Transparency Through Liability Insurance}

Arguably, liability insurance reduces the transparency of the civil justice system by facilitating a private, bureaucratic claims management approach to insured liabilities rather than the public, adversarial justice approach of the courts. In my view, such a bureaucratic claims management approach would be an inevitable feature of any functioning civil justice system in a massmarket economy. Others may disagree, but as a practical matter, changing to a more individualized justice approach would require a commitment of such vast public resources that such a change lies outside the scope of the immediate public policy debate.

With that said, there is no reason why the presently private nature of claims management cannot be brought into public view, though that result cannot be accomplished without government action. As noted earlier, insurance is a very competitive business, and superior information about claims can provide a competitive advantage to larger insurers. It is not in their interest to share that information with potential competitors, and we cannot expect them to do so voluntarily. With the exception of the auto claims data provided by

9. The NCCI information is based on a telephone interview with Barry Llewellyn of NCCI, together with information gathered from the NCCI website, http://www.ncci.com. 
the Insurance Research Council, all of the most important sources of data described in this chapter are the result of government mandates.

The NCCI-administered workers' compensation claims reporting system, the NPDB, and the medical malpractice closed claims reporting systems in Texas, Florida, and Missouri provide models on which to build. In adapting those systems to better serve transparency goals, it would be essential to seek the input of civil justice researchers who have worked with those systems.

The NAIC's Model Law is one such example, but the decision to leave open the issue of researcher access demonstrates that medical and insurance industries have at least partially succeeded in their efforts to deny public access to the closed claim reports. Additionally, the model law does not require insurers to file reports on "no payment" cases despite the fact that the state of Missouri has done so in the past with no apparent negative impact on the state's liability insurance industry. Like many such NAIC efforts, the medical malpractice model law drafting process appears to have been dominated by insurance industry interests, in part because of the inevitable tendency for specialist regulators to begin to see the world through the eyes of the high-status people whom they regulate (Randall 1999). For that reason and because of the significance of uninsured liabilities in fields such as medical malpractice and products liability, efforts to create truly transparent claim reporting systems should be informed by the insurance industry and insurance industry regulators, but should not take place within the field of insurance regulation.

The NPDB, which was established by federal legislation, provides a partially successful model, subject to the important caveat regarding the lack of reporting obligations for defendants other than doctors. The NPDB does not contain records of payments by hospitals and other entity defendants. This reporting differential skews the transparency provided by the NPDB in two ways. First, there is the obvious consequence that the NPDB only provides a partial view into medical malpractice payments. Second, in cases with both an entity defendant and an individual defendant, there is an incentive to craft the settlement so that the entity, but not the doctor, pays. This incentive is particularly strong in situations in which the doctor and the entity have the same insurance arrangements. Any effort to increase transparency in the future must be crafted to avoid such gaps in reporting obligations. Other limitations of the NPDB include the reporting of claim payment amounts by dollar ranges rather than by absolute amounts (which makes statistical analysis more difficult) and the lack of standardized injury severity information such as the 9-point scale developed by the NAIC. 


\section{Conclusion: Limits on Transparency Through Liability Insurance}

This chapter has described some of the main ways that liability insurance data and institutions contribute to the transparency of the civil justice system. Because this contribution differs substantially across lines of insurance and because some liabilities are not insured at all, aggregate liability insurance data do not provide a reliable guide to the size or scope of the civil justice system as a whole. At best, the data provide a guide to those portions of that system that involve commonly insured liabilities. As illustrated in this chapter, the extent to which they provide a reliable guide differs significantly from one type of liability to another.

The single best way to improve the transparency of the civil justice system would be to expand mandatory claim-level reporting along the lines suggested in this chapter. These reporting requirements would impose a burden on the liability insurance industry. They would also impose a burden on the large organizations that use alternative risk transfer and reduction mechanisms. These burdens are worth imposing for at least two reasons. First, civil justice transparency is a valuable public good. Second, the liability insurance industry and other large organizations have been vigorous supporters of restrictive civil justice reform, in part based on unverified claims about the wasteful costs that civil justice institutions impose on U.S. society. It is reasonable to require organizations that make such claims to provide public access to the data that are required to evaluate them.

In concluding, it is worth noting that this chapter provides yet another illustration of how liability insurance complicates the ability to observe the civil justice system. There is no "pure" civil justice system that liability insurance can help us observe. Liability insurance transforms civil justice claims even as it helps make them more observable. Liability claims are shaped to match the available liability insurance, with the result that "exclusions in liability insurance policies create, in effect, remote islands of tort liability that lawyers and law professors know about, but almost no one goes to visit" (Baker 2006, 7). Liability insurance transforms claims against individuals into de facto claims against massively repeat players-insurance companies. Liability insurance limits are de facto caps on damages. Liability insurance claims personnel transform some complex liability rules into simpler, more 
administrable rules of thumb. And negotiations over the boundaries of liability insurance-who is obligated to buy liability insurance, in what amounts, and against which liabilities-amount to negotiations over the boundaries of the civil justice system itself.

There is no system of civil justice that liability insurance institutions can help us observe without transforming that system. As Kenneth Abraham has compellingly documented, "The tort system, not only as it exists on paper, but also how it works in practice, is a product of the insurance system, just as the insurance system is a product of the tort system" (Abraham 2008, 1). 